\title{
圈 \\ The What, Why and How of Generic Skills: A Financial Planning Case Study
}

\author{
Craig Cameron ${ }^{1}$, Mark Brimble, Julie Knutsen \& Brett Freudenberg, Griffith University
}

\begin{abstract}
Financial planning in Australia is moving away from its traditional characterisation as an "industry" and towards a "profession". A key feature of any profession is an educational framework that facilitates the development of technical knowledge and generic skills by students so that they can successfully transition into the workplace. The Australian Securities and Investments Commission (ASIC) is currently reviewing changes to that educational framework (ASIC 2011; ASIC 2013), while the Financial Planning Association (FPA) has recently introduced revised and enhanced educational requirements through the Financial Planning Education Council (FPEC) (FPA 2010; FPEC 2012). Stakeholder input will be critical for the development of financial planning education programs that meet the higher standards of a profession. In particular, what are the generic skills needed by financial planners; and which are currently seen to be most deficient? This paper is an instrumental case study involving interviews with 24 financial planning firms which explore the what, why and how of generic skills. This qualitative study provides a greater insight into generic skills by identifying skill importance and deficiency, as well as possible solutions to assist with the financial planning industry moving to a profession.
\end{abstract}

Key Words: generic skills; financial planning; profession; graduates; educational framework

JEL Classification: I21; I29

\footnotetext{
${ }^{1}$ craig.cameron@griffith.edu.au
} 


\section{INTRODUCTION}

A key component of financial planning moving away from an "industry" and towards a "profession" in Australia is an educational framework ${ }^{2}$ which facilitates the development of both technical knowledge and generic skills. Technical knowledge represents knowledge about a particular discipline area (such as superannuation) whereas generic skills are not discipline-specific and can be applied to a variety of contexts, including higher education and the workplace (Bennett, Dunne \& Carre 1999). Educational standards have traditionally failed to keep pace with the growth of financial planning services and the growing complexity of technical knowledge and generic skills required. The Australian Securities and Investments Commission (ASIC) attempted to standardise entry requirements through PS 146 (now RG 146). However, the large volume of participants and commercial pressures to provide faster and cheaper educational programs led to incoherency (FPA 2009). In response, the Financial Planning Association (FPA) formed the Financial Planning Education Council (FPEC). FPEC released a curriculum and accreditation framework in 2012 which established degree level studies in financial planning and accreditation processes for providers as the requirement for membership of the professional body (FPA 2010; FPEC 2012). ASIC also released CP 153 which details an assessment and professional development framework for financial advisors (ASIC 2011). This was followed by a consultation paper that proposes a move to AQF level 7 (Bachelor level) by 2019 for RG146 training standards. These developments highlight the push for higher education standards across the sector. However, there is little agreement between stakeholders with the FPA/FPEC proposals not aligning with the proposed RG146 framework which remains product area based and in a competency, rather than professional standards, framework. This is further exacerbated by the changes necessitated by the socalled Future of Financial Advice reforms which are changing planning practice and may lead to additional skill and knowledge requirements.

In terms of generic skills in financial planning there has been little scholarly attention. The main exception is Jackling and Sullivan (2007) who undertook a quantitative study of skill importance and competency of financial planners. In a survey distributed to FPA members, respondents were asked two questions: (a) which skills are perceived as the most important for career success by financial planners? (skill importance); and (b) How do financial planners rate the standards of technical and behavioural (generic) skill acquisition of recently qualified financial planners recruited in the past three years? (Competency). This revealed that listening skills were ranked the most important skill, with the greatest skill deficiencies in listening and questioning skills (behavioural) and superannuation and retirement planning (technical) (Jackling \& Sullivan 2007). The findings confirmed anecdotal evidence and industry surveys highlighting skill deficiencies in financial planners.

This paper expands the literature on generic skills in financial planning education through a qualitative study of 24 financial planning firms that had recently recruited an intern and/or a graduate completing a degree in financial planning. During semi-structured interviews, financial planners and practice managers were asked to select the three most important skills sought when recruiting graduates or interns and the three skills that interns/graduates are most deficient in. The study then moves beyond the "what" of generic skill importance and competency addressed by Jackling and Sullivan (2007) to the "why".

\footnotetext{
${ }^{2}$ The professional education framework refers to the entry and ongoing educational requirements for practitioners articulated through a knowledge and skills framework.
} 
Respondents were asked why they selected the three skills as most important and most deficient. This contextualises generic skills by enabling employers to ascribe their meanings to those skills (Tempone et al. 2012). The study provides a third dimension to generic skills by seeking industry input on "how" generic skills could be incorporated in education programs to address the skill deficiencies. In particular, respondents were asked to draw on their own education experiences (including continuing professional development) and identify learning activities that could improve the generic skills of interns or graduates. It is argued that this rich qualitative data can make an important contribution to the formulation of an education framework that equips students with the skills required to be successful financial planning professionals.

The next section of the article provides a theoretical background to the generic skills debate in higher education generally, before addressing the literature specific to financial planning education. This is followed by the research method and qualitative case study which addresses three broad research questions: (i) what are the three most important generic skills when hiring a graduate and why?; (ii) what are the three skills that graduates are most deficient in and why?; and (iii) what learning activities would financial planning firms incorporate into a course that entails generic skills? The article concludes with a discussion of the limitations and potential for future research.

\section{THEORETICAL BACKGROUND}

\section{Generic Skills in Higher Education}

The generic skills debate in higher education has been characterised by: issues of definition; industry concerns about the generic skill levels of graduates; and studies which support as well as attempt to address those industry concerns. The proliferation of terms used to describe generic skills such as “transferable”, “employability”, “graduate”, “employment related” and "professional” has created confusion about its definition (Bennett et al. 1999; Barrie, Hughes \& Smith 2009). For example Dacre Pool and Sewell (2007) argue that employability is not a skill in itself but is a combination of career development learning, work and life experience, technical knowledge, generic skills and emotional intelligence. To minimise any such confusion in this study, the following definition is adopted from Bennett, Dunne and Carre (1999):

'The skills which can support study in any discipline, and which can potentially be transferred to a range of contexts, in higher education or the workplace' (p76).

Not only are generic skills transferable, but they are essential in enabling students to apply their technical or discipline specific knowledge to a range of contexts (Jackson 2013).

Student self-efficacy has an important relationship with generic skills. Students may possess the generic skill but not the self-efficacy to properly apply that skill when completing a task. Definitions of self-efficacy commonly stem from the seminal research of Bandura (1977, 1982). An individual's self-efficacy represents their self-confidence in their ability to organise and execute a course of action to obtain certain outcomes. Self-efficacy can be changed by learning from mastery experiences, social modelling and persuasion (Gist \& Mitchell 1992). There is broad agreement that a higher level of student self-efficacy in generic skills correlates to improved work-readiness and enables students to make meaningful judgements of their actual skill levels (Sugara, Suzuki \& Boland 2010; Duijnhouwer, Prins \& Stoking 2012; Hassall et al. 2013). For example Freudenberg et al. (2008) found that a 
student-industry conference, a mastery experience supported by generic skills training and social modelling, improved the self-efficacy of accounting and financial planning students in communication and interpersonal skills.

\section{Skills-Expectation Gap}

For the past twenty years professional associations, academics and employers have driven the generic skills debate in higher education by articulating the generic skills required of graduates, the importance of those skills and the skill deficiencies in graduates. The subsequent research has identified industry concerns with the generic skill capabilities of graduates, such that a gap exists between employer expectations and generic skill levels (the “skills-expectation gap”) (ACCI \& BCA 2002; Precision Consultancy 2007; Kavanagh \& Drennan 2008; Tempone et al. 2012). Employers of business graduates have emphasised business awareness, problem-solving, oral and written communication, interpersonal skills and team work as the most important generic skills (Merino 2006; Krause 2007; Kavanagh \& Drennan 2008; AAGE 2011). In fact accreditation bodies require universities to include generic skills in the curriculum as part of a quality assurance framework in accounting and business education (AACSB 2013; ICAA \& CPA 2012). Despite this, graduates are not meeting employer expectations in the previously mentioned generic skills they deem most important. According to both educators and employers of business graduates, this may be due to the tertiary focus on technical knowledge at the expense of learning activities which promote generic skills development (Kavanagh \& Drennan 2008; Jackling \& De Lange 2009; Jackson \& Chapman 2012).

\section{Work-Integrated Learning}

Universities have employed Work Integrated Learning (WIL) activities as a method of bridging the skills-expectation gap (Patrick et al. 2008; Universities Australia 2008). WIL describes any educational activity that integrates formal learning and workplace experience within a curriculum (Atkinson et al. 2005). Cooperative education, practicum, internship, work placement and service learning are commonly cited examples of WIL. A number of studies have identified the positive impact of WIL programs on self-efficacy, career and professional knowledge and generic skills using student self-reported quantitative and qualitative data (Tucker \& McCarthy 2001; Freudenberg, Brimble \& Cameron 2010; Wilton 2012; Jackson 2013). A study by Wilton (2012) of business and management graduates in the UK found that the "value-add" of a work placement may not necessarily be the greater development of generic skills, but rather personal development in self-confidence (an element of self-efficacy) and a better understanding of the work environment and employer expectations (career and professional knowledge). This finding is supported by contemporary research that WIL programs improve students' professionalism (Jackson \& Chapman 2013) and professional understanding (Freudenberg et al. 2010). In particular, the workplace environment offers professional orientation and socialisation (Blackwell et al. 2001) and a space for students to develop their professional identity (Freudenberg, Brimble \& Cameron 2009; Trede 2012). 


\section{Generic Skills in Financial Planning Education}

Before the 1990s, little attention was paid to the education standards of new entrants into the financial planning industry (Jackling \& Sullivan 2007; Warschauer 2002). In Australia, following the introduction of compulsory superannuation, the volume of superannuation and related financial products being sold created significant growth in the financial planning industry (Jackling \& Sullivan 2007). The growth attracted many new entrants, and the potential for increased business followed with employers preferring candidates with strong sales skills over higher education (Cull 2009). The emphasis on sales skills changed in 2002 with the introduction of the Financial Services Reform Act (Bruce \& Gupta 2011; Cowen, Blair \& Taylor 2006). Underpinning these reforms was an acute awareness that quality financial advice required a higher level of education and a wider and more specialised range of skill sets (Jackling \& Sullivan 2007; Cowen, Blair \& Taylor 2006). In particular, hard skills (i.e. technical and specialised financial knowledge) and soft skills (i.e. cognitive and behavioural) were described as essential foundations for new entrants to the financial planning field (Bruce \& Gupta 2011; Jackling \& Sullivan 2007). These skills were enforced under the Regulatory Guideline 146 (RG146) as the minimum educational standards required for those providing financial planning and product advice (ASIC 2009).

There is agreement that RG146 has been the catalyst for standardising the skill requirements for financial planners (FPA 2009; ICAA 2007). However, ASIC investigations revealed deficiencies in the quality of financial advice (ASIC 2003; 2006; 2011), with each investigation referring to inadequate adviser skills as the source of the problem. The FPA and the Institute of Chartered Accountants in Australia (ICAA) subsequently contended that skill sets defined by RG146 have not facilitated the provision of quality advice and not addressed the changing financial needs of Australians (FPA 2009; ICAA 2007). Following their investigations, ASIC released Consultation Paper 153 (CP 153) calling for industry feedback on the raising of minimum education standards to the degree level, greater emphasis on continuing professional education and national examinations for advisers (ASIC 2011). A further consultation paper (CP212) was recently released that proposes to increase the qualification level of the training standards (to Bachelor level) and also extend the breadth of the knowledge components.

Despite the concerted efforts of stakeholders to strengthen the educational framework for financial planning, the debate concerning the generic skills and attributes considered critical for a new generation of financial planners continues. The FPA's position is that new entrants to the industry need well developed financial and analytical skills, critical thinking faculties and ethical questioning techniques which prepare them for complex client relationships (FPA 2009). Martin (2007) and Rossetto and Murphy (2010) identified written and oral communication as critical generic skills for financial planning advice and analysis. Purnell and Levy (2011) described more specific key attributes which included the ability to gather information, to understand a client's needs and be able to articulate the value of professional financial advice in a complex world of regulation, tax laws and financial product features. In the United States, Goetz et al (2005, 2011) has advocated professional practice courses which entail education in generic skills such as negotiation, networking, CV writing, business communication, client management and career planning, as well as professional certification in financial planning exams in order to improve student employability. Furthermore, while the previously mentioned Financial Planning Education Council 
framework sets a national curriculum for financial planning, it does not go so far as to set a detailed generic skills matrix.

The most comprehensive study of generic skills in financial planning from a stakeholder perspective is Jackling and Sullivan (2007). The research design involved a survey instrument mailed out to financial planners registered as FPA members. A total of 162 respondents ranked a set of ten technical and generic skills from 1 (least important) to 10 (most important). Listening skills were rated as the most important skill [mean $=8.53$ ], followed by oral communication [7.22] and questioning technique [6.46]. The least important skill was "awareness social and ethical problems" [2.53]. The research findings on skill deficiency involved the measurement of two variables (importance and competency) on a five point Likert Scale and calculation of their respective means for each skill. This meant that the authors could undertake paired-sample t-tests to assess the statistical significance of the difference between means. The mean difference demonstrated the "gap" or skill deficiency. The greatest generic skill deficiencies were listening skills (0.97 mean difference), questioning technique (0.90) and time management (0.70).

Jackling and Sullivan made a valuable contribution to the literature by identifying skill importance and deficiency in financial planning. Nevertheless the quantitative research design prevented the authors from obtaining a richer understanding of the phenomenon being studied - generic skills. For example, qualitative research would have enabled the authors to study the meanings financial planners ascribed to each of the ten skill sets and identify which aspects of listening skills and questioning technique were important and/or deficient. In addition, we are more specific with our sampling to ensure that the interviewees' comments are based on experiences with students completing financial planning degrees, which traditionally has not been the case.

The study in the sections which follow extend this research by gaining a deeper understanding of the 'what', 'why' and 'how' of generic skills. We argue that knowing both the 'what' and the 'why' of generic skills is critical in determining 'how' financial planning education can deliver a curriculum which equips graduates with the generic skills necessary to offer professional advice to their clients.

\section{RESEARCH METHOD}

The case study was carried out as part of an annual industry review of a professional business degree offered by an Australian university (the Professional Degree). Students enrol in a financial planning and/or accounting major, study full time for one year on a trimester basis and then complete a two year paid internship whilst studying part time in their second and third years. During the three year degree, students participate in a continuing professional development program (PD Program) designed to improve their generic skills and selfefficacy. The Professional Degree has been previously described and examined in the literature from a student (Freudenberg et al. 2009, 2010) and stakeholder perspective (Brimble et al. 2012).

To build upon this knowledge base an instrumental case study design was adopted in order for the authors to obtain a rich understanding of generic skills from a stakeholder perspective (Stake 1995). Industry partners who had employed one or more interns and/or participated in the PD Program were contacted to participate in the study. A total of 42 industry partners comprising of practice managers, Human Resource managers and accounting and financial planning professionals participated in semi-structured interviews of 
between 15 to 60 minutes. To ensure consistency one of the authors conducted all of the interviews. The interview questions (IQ) relevant to this study were:

(i) IQ 1: From the 9 generic skills areas on the sheet, what are the three most important skills you seek when recruiting interns (if interns) /graduates (if no interns)? Why? (Skill Importance);

(ii) IQ 2: From the 9 generic skills areas, which three skills are the intern students (if interns) / graduates (if no interns) most deficient in? Why? (Skill Deficiency) and

(iii) IQ 3: If you could construct a course dealing with professional skills as opposed to technical skills (or theoretical knowledge), what learning activities would you suggest be included to improve your graduates/interns’ skills? (Learning Activities to Improve Skills) ${ }^{3}$

The nine generic skills listed were: interpersonal; oral communication; self-management; problem solving; conceptual and analytical; teamwork; information literacy; written communication; and learning and adaptability. These were selected from prior literature (Lizzio \& Wilson 2004) and consistent with the set employed in Freudenberg et al (2010) which examined accounting and financial planning students' perceptions of their skill development. Industry partners also had the option of providing additional skills not covered. If industry partners queried the meaning of skills, the interviewer relied on the behaviourally specific statements from a survey instrument used in the previous quantitative research (Lizzio \& Wilson 2004). The requirement of participants to select three and not one important skill and skill deficiency enabled the authors to identify themes and explore them in the section "Results and Discussion". This section, which follows the descriptive statistics, is organised according to the three interview questions addressing skill importance, skill deficiency and learning activities to improve skills (IQ 1, 2 and 3). In the case of skill importance and skill deficiency, the quantitative data is tabled according to frequency with the qualitative data from the four highest frequencies explored to tease out the reasons why those skills were most important or deficient. With respect to IQ 3, participant responses are categorised by frequency under two broad themes - learning activities and generic skills with a description of the learning activities recommended by participants to improve graduates’ generic skills.

\section{Descriptive Statistics}

For the purpose of this study, the 42 industry partners were classified into accounting and financial planning participants. While some industry partners operated a multi-disciplinary practice, in each instance there was a clear majority of accountants or financial planners in the practice which was used as the basis for classification. This resulted in 24 financial planning and 18 accounting firm participants being identified. The descriptive statistics for the financial planners in the sample are set out in Table 2. Rather than provide a definition of financial planner as in Jackling and Sullivan (2007), participants were asked to identify the number of financial planners and paraplanners in their firm so that financial planners were distinguished. The vast majority of participants interviewed were from firms with five or less financial planners (88\%), which is consistent with the sample in Jackling and Sullivan (2007). The sample comprised of 19 financial planners (79\%) and five practice managers (21\%).

\footnotetext{
3 The remainder of this paper will use the term 'graduate' given that paid internships in financial planning degrees are uncommon in Australian universities.
} 
Consequently, given the nature and size of the sample a detailed comparative analysis by firm size and occupation is beyond the scope of this study.

Table 1: Descriptive Statistics - Number of Financial Planners by Firm Participant

\begin{tabular}{|l|c|}
\hline \multicolumn{1}{|c|}{ Number of financial planners in firm } & Frequency \\
\hline 1 & 5 \\
\hline $2-3$ & 10 \\
\hline $4-5$ & 6 \\
\hline More than 5 & 3 \\
\hline
\end{tabular}

\section{RESULTS AND DISCUSSION Skill Importance}

The interview responses to IQ 1 - identifying the three most important skills participants seek when recruiting a graduate - were aggregated according to the nine skills and are displayed in Table 2. Based on frequency, the four most important skills (in descending order) were: problem solving; oral communication; interpersonal and learning and adaptability. These results support Jackling and Sullivan's quantitative study in which "listening skills" (interpersonal), “oral communication”, “questioning technique” (interpersonal) and "resolve financial problems" (problem solving) were identified as the four most important skills from ten skill sets. Table 2 also shows that one participant provided an additional skill (ethics). Ethical understanding could be considered part of technical knowledge (not covered in the study) and ethical awareness a generic skill. The participant explained the importance of ethics in the context of motivation, that is, the graduate must be motivated to help clients solve their financial problems. The following section explores participant responses as to why problem solving, oral communication, interpersonal and learning and adaptability skills were the most important skills and the meanings they ascribed to those skills.

Table 2: Skill Importance - what are the three most important skills you seek when recruiting graduates?

\begin{tabular}{|l|c|c|}
\hline \multicolumn{1}{|c|}{ Skill } & Frequency & Participants (\%) \\
\hline Problem Solving & 13 & 54 \\
\hline Oral Communication & 12 & 50 \\
\hline Interpersonal & 11 & 46 \\
\hline Learning and Adaptability & 9 & 38 \\
\hline Teamwork & 7 & 29 \\
\hline Self-management & 7 & 29 \\
\hline Written communication & 5 & 21 \\
\hline Information Literacy & 4 & 17 \\
\hline Conceptual and Analytical & 3 & 13 \\
\hline Ethics & 1 & 4 \\
\hline
\end{tabular}

\section{Problem Solving}

Three themes underlying problem solving were 'initiative' (9 from 13 responses); 'financial planning role' (2) and 'lateral thinking' (2). It is interesting to note that all 13 responses were from financial planners. This may be explained by the fact that financial planners work with graduates on a daily basis solving problems as opposed to practice managers whose involvement with the graduate is generally related to HR processes. According to the financial 
planners, initiative required the graduate to approach supervisors with solutions, not just problems. For example:

'I was always taught to bring my boss solutions not problems. There's nothing worse than someone knocking on your door every half hour saying 'what do I do next' or 'how do I do this' or 'what do I do here'. Look at the problem yourself and if you are still stuck come in with a couple of solutions of what you would do.'

Financial planners were not particularly concerned that the solution was incorrect, but that the graduate had demonstrated the initiative to present a solution rather than constantly interrupting their supervisor seeking a solution from them. As one financial planner put it:

'Instead of coming to us with 'what's the solution?' come to us with two solutions of your own. If they are rubbish solutions that's fine - at least they've had a go at trying to solve the problem themselves.'

Two participants explained that problem solving skills were important because this was the role of financial planners, namely to "identify a problem, or fact or circumstance and provide a solution". Nevertheless, initiative took precedence over the role of financial planners. This is not surprising given that graduates are not expected to have the same level of technical knowledge as a financial planner. It appears the participants were more interested in identifying whether the graduate had the initiative required of a financial planner to solve problems. Financial planners also noted that graduates needed to exercise lateral thinking or "thinking outside the box" to solve a problem because "no two things are really ever the same in this industry [and] no two clients will be the same”.

\section{Oral Communication}

The four most common themes for oral communication were "client communication" (6 from 12 responses), "occupation" (4) and "confidence” (2). Graduates were required to "interact with", "talk to" and "have a conversation with" clients. Most graduates commence in a customer service role, with client contact generally limited to obtaining client information or receiving instructions over the telephone. Participants saw confidence was crucial in this setting:

'Answering phones for a starter when they are talking to clients, and then relaying that message onto clients or the relevant person in the office. Asking questions really, asking the right sort of things that they need to know at that point rather than accepting what's been said to them and saying yes or no just having that confidence.'

Participant responses concerning confidence are supported by the literature on self-efficacy in oral communication skills (Tucker and McCarthy 2001; Freudenberg et al. 2008; Hassell et al. 2013). Graduates may have acquired oral communication tools during their degree but do not necessarily possess the self-efficacy to effectively use them. Those who judge themselves as inefficacious will avoid activities they perceive exceed their capabilities and until that selfbelief is elevated, that perception will remain their reality (Bandura 1982).

There were opposing views concerning the differentiation of skill importance by occupation. Two participants distinguished financial planners from other occupations. Both participants (financial planners) were forthright in the career prospects of a graduate without proper oral communication skills. For example:

'If they are looking at being a financial planner, and they do not have oral communication skills, the ability to talk to somebody one on one, the ability to present to a group then they are not going to really make it as a financial planner.' 
The other two participants considered that the importance of oral communication skills was not financial planning specific and was broader. In fact oral communication was "the key to ensuring a successful and effective workplace”.

\section{Interpersonal Skills}

The two primary themes for interpersonal skills were "relationships" (6 from 11 responses) and "professionalism" (2). It was apparent that participants made the distinction between oral communication and interpersonal skills. As one financial planner noted, "sure you can be a great communicator but to be great at what we do you need to be able to build relationships". The financial planning practice was "all about our relationship with clients". Interpersonal skills such as "when to talk and when to listen" to clients of different types was imperative in developing relationships. Without the ability to build client relationships, participants conceded that "it's going to be an uphill battle regardless of how much they know" and the graduate may be more suited to a paraplanner or analyst position.

Participants acknowledged that relationship building involved both clients and co-workers. The financial planner was part of a team including paraplanners and customer service staff:

'They have to be able to relate to the clients but they also have to be able to come outside and relate to the paraplanners that are reliant on them, the client relationship officers because they work in a team, and if one of those relationships is down then obviously the team suffers and the output doesn't go out.'

The potential domino effect associated with poor co-worker relationships is particularly important given that many financial planning firms can be small. One financial planner used an analogy to illustrate the importance:

'I always use the example of the dinghy ... if you've got a big large ship and if you jump up and down in the corner people don't feel it, but when you're in an environment like this then you do. And it has a massive ripple effect.'

A graduate lacking interpersonal skills can undermine the office environment and represent a weak link in the chain that compromises firm reputation and service to the client. For two participants, interpersonal skills were directly related to professionalism: "it's the core of everything we do as professionals". Clients expect when entering the firm office that it is a professional environment and as such, graduates will possess good interpersonal skills.

\section{Learning and Adaptability}

"Willingness to learn” (3 from 9 responses), “processes” (4) and “application of workplace learning" (2) were the three common themes associated with learning and adaptability skills. In a financial planning environment characterised by new products, pricing models and regulations “you have to be able to adapt to what's happening in our industry and learn”. As one financial planner put it:

'If you don't embrace the word change you will fall by the wayside because I've seen it with the older advisors - they put brick walls up, I don't want to do an SOA because I've never done one before.'

Two practice managers focused on the importance of graduates applying their workplace learning. They distinguished application of workplace learning from problem solving. Graduates who were unable to solve a problem sought advice and feedback about the solution and applied it the next time they encountered the problem: "that to me is not problem solving. 
That is a learning routine”. Closely related to applying workplace knowledge is the graduates' willingness to learn in the workplace:

'So if I was interviewing a grad, I want to see that whilst they may be smart, I want to see that they get that they have a lot to learn...'

In particular, participants wanted graduates to learn processes, namely "being able to quickly grasp the way that we do things and to be able to understand the reasons why". Learning the processes may even enable graduates to "improve on the processes that are already there". One financial planner divided their practice into four areas and described the processes associated with each.

'The administration side of things so there is a processing and administration of all our files, plans and statements of advice and so forth; The paraplanning part which is learning the process of how a plan is developed which includes the research and analysing the information that comes in, loading it onto our computer programs; The analytical part which is analysing the data that comes out of the information that's provided by the client; The compliant side of things, which is making sure that everything we do in here is compliant, it's legal, meets all the requirements so that we are able to deliver quality advice every time without any fail.’

Graduates needed to learn the processes in all four areas because they form "the basis of what a financial planner should know before they become a financial planner”.

\section{Skill Deficiency}

From the same list of nine skills in Table 2 above, participants were then asked to identify the three skills that graduates or interns (as the case may be) were most deficient in (IQ 2). Responses were aggregated according to the nine skills and are displayed in Table 3. Based on frequency, the four greatest skill deficiencies (in order) were: written communication; interpersonal; problem solving; and conceptual and analytical. These results provide some support for Jackling and Sullivan's study which measured the standard of skill exhibited by recently employed financial planners. "Time management skills” (self-management), "questioning technique” (oral communication), "presentation skills" (oral communication) and "listening skills" (interpersonal) had the four lowest mean standards from a list of eight non-technical skills. The following section explores participant responses as to "why" written communication, interpersonal, problem solving and conceptual and analytical were the most deficient skills.

Table 3: Skill Deficiency - which three skills are the graduates most deficient in?

\begin{tabular}{|l|c|c|}
\hline \multicolumn{1}{|c|}{ Skill } & Frequency & Participants (\%) \\
\hline Written communication & 15 & 63 \\
\hline Interpersonal & 12 & 50 \\
\hline Problem Solving & 11 & 46 \\
\hline Conceptual and Analytical & 10 & 42 \\
\hline Oral Communication & 9 & 38 \\
\hline Self-management & 6 & 25 \\
\hline Teamwork & 4 & 17 \\
\hline Learning and Adaptability & 3 & 13 \\
\hline Information Literacy & 2 & 8 \\
\hline
\end{tabular}




\section{Written Communication}

Nearly two thirds of all participants stated written communication as one of the three greatest skill deficiencies in graduates. In particular, participants focused on e-mails and letters to clients and service providers such as insurance companies and fund managers (10 from 15 responses). One financial planner expressed his frustration in these terms: "We have to proof read the letters because sometimes they are that bad they can't go out to a client."

Whilst financial planners noted that the use of templates solved some of the written communication problems (2), graduates' lacked the ability to properly structure (5) and use appropriate language (5), in other words "communicating in a manner which the client will understand". In terms of language, graduates were: over reliant on spell check - "Things like spell check are an issue though because if the computer doesn't pick up the mistake they won't either". Also graduates would say "something really personal” in professional e-mail communications and use unprofessional language in professional communications. On the latter point, one financial planner noted how poor written communication can jeopardise the firm's reputation:

'So, "ewes" refers to female sheep, not a group of people. If you're writing to an educated audience and you write "yous", they just groan. That is under-rated. It's an insight into my business that people see and they go "well the people that work here aren't fundamentally literate".'

Whilst graduates completed written assignments at university, this written communication skill does not appear to be transferable to a workplace context where letter and e-mail writing involves a different structure. One practice manager explained that graduate communications were either "very drawn out and long and you have to go what the hell is this person asking me" or they "have no idea how to draft the communication". Graduates also failed to appreciate that structure varies depending on the recipient. Financial planners noted that whereas a complex document such as a Statement of Advice should incorporate flowcharts and diagrams to facilitate client understanding, writing to a fund manager required a different structure to elicit understanding.

\section{Interpersonal}

The three common themes associated with interpersonal skills were "experience" (4 from 12 responses), "personality" (3) and "emotional intelligence" (2). Participants acknowledged that the interpersonal skill of building relationships with clients and co-workers came with experience and was part of the graduates' life-long learning in financial planning. As one financial planner put it "you don't get taught those skills at uni”. The transition from university to the workplace was a "culture shock" for graduates who did not have previous office experience. Graduates' reticence to reveal their true personality to co-workers and clients was stifling the development of their interpersonal skills. The personalities of graduates were "quite closed", they "needed to open up a bit" so that they could "fit in" to the practice. Participants suggested that experience and confidence were important factors. For example:

'I don't know if it's a confidence thing or what. I see a lot of potential in him (I don't think he sees it yet). He's not quiet but he doesn't let his personality shine through as much as he should or could.'

The graduates' emotional intelligence was discussed in the context of client and co-worker relationships. For example, a graduate received a concession from their boss and proceeded to tell colleagues. This was a lesson on "how not to be popular in about two seconds". According to one financial planner, the experience of the Global Financial Crisis had 
highlighted the importance of graduates acquiring emotional intelligence as well as technical knowledge:

'when you're sitting in front of clients who have just lost half a million bucks.... how do you approach that? And, you know, there is a lot of emotional intelligence required in that, doesn't matter how smart you are, you're tapping in, you need to tap into their emotions, and you know, I guess, you need a bit of TLC around that area.'

\section{Problem Solving}

Given the emphatic result under skill importance, it is no surprise that the key theme underlying skill deficiency was "initiative” (8 from 11 responses). According to participants, a lack of initiative manifested itself in a number of ways. The graduate "waits for instruction to go and do something". Graduates were "asking too many questions all the time", "continually running over to someone and saying can you help me with this" and "seeking the solution before they've even thought about it". Laziness ("I'll just ask the question, it's easier”), passivity, "not knowing where to start" and "not knowing what to do next" were the main reasons proffered for this solution seeking behaviour. The graduates' deficiencies in problem solving skills hindered task completion, particularly tasks that were not part of the graduates' ordinary course of work:

'If they are assigned a task and then for whatever reason a particular task isn't a normal flow of the processes it just seems to come to a grinding halt.'

Graduates unable to complete the task were either seeking the solutions from supervisors or avoiding the task (taking "the passive route out" or even avoiding the supervisor!).

\section{Conceptual and Analytical}

Understanding of "context” (5 of 10 responses), "experience” (4), "application of technical knowledge" (3), and "attention to detail” (2) were the common themes underlying graduate deficiencies in conceptual and analytical skills. A number of planners acknowledged that the development of conceptual and analytical skills came down to experience:

'One of the common problems I've found is... the knowledge is given to you but there is no context around it the understanding of how it applies to real life isn’t there. The ability to analyse the information as it comes through and applying that to your knowledge, I find there is definitely a disconnect there. How you can improve on that I'm not sure. Whether that's just experience through working in the field... you usually gain that knowledge and ability.'

In terms of conceptual skills, graduates needed to understand how their tasks fit within the financial planning process. They needed to "actually see what the task is and how important it is in the bigger picture”. As one financial planner explained:

'Understanding there is a whole process that needs to take place. It's not just you know, understanding that $15 \%$ is tax from superannuation contributions. Those sorts of things you can learn.'

The inability to apply technical knowledge in the workplace and to exercise attention to detail was the key deficiencies in analytical skills. This was a source of frustration for one practice manager in a large financial planning firm who has had to incorporate conceptual and analytical skills into the induction process. She expected that graduates would enter the workplace and be able to apply their knowledge to specific scenarios. One financial planner expressed the difference between knowledge and application as "theory versus practicality":

'normally one of the first questions I ask a new recruit when they first start with us, when I just work out their training plans, is we'll tell them about insurance. And invariably they go back to the normal default sort of textbook stuff, but it's about how that applies and how it might apply.' 
Overall, the analysis reveals that interpersonal and problem solving skills were considered the most important but also the most deficient skill sets amongst graduates. Written communication was the most emphatic result amongst skill deficiency and importance. In particular, graduates need to learn how to write a professional e-mail and letter and have the capacity to build relationships. Initiative within problem solving skills was the most frequently cited theme. The ability to solve a client's financial problems may be the foundation of financial planning, but employers were more concerned with the graduates' initiative in approaching them with solutions. Whilst participants acknowledged that experience was important, the general perception was that higher education could do more to equip students with these skills. The learning activities that financial planners and practice managers suggest could be included in the curriculum, namely the "how" of generic skills, are discussed in the section that follows.

\section{Learning Activities to Improve Skills}

The third and final interview question required participants to identify the learning activities that they would include in a course to improve the professional skills of graduates (IQ 3). The range of professional or generic skills included client communication (people skills, building rapport) (11 responses), written communications (10), professionalism (9), telephone skills (8), self-awareness (body language, presentation) (7), handling objections/complaints/conflict (5), active listening (4) and team work (4). This is largely in line with the discussion above, however highlights the areas of concern to the interviewees.

In terms of learning activities to build these skills, there was a clear consensus amongst the interviewees with role playing, presentations, business writing and observation being commonly suggested. Role play was the most prevalent with eleven participants arguing for full planning process role plays including initial interviews, fact find interviews, plan presentations and follow-ups. Others extended this to business telephone conversations role-play (8 responses) and employment interviews (6). Others mentioned professional dress as a key issue in terms of authenticity and professional awareness and preparation. There was a strong emphasis on practice and active learning through participation:

'It's [client communication] a bit like having read the manual about Honda and understanding exactly how Honda works and everything about it, but you've never seen or touched one.'

'How to answer the telephone, how to speak, how to respond. Not yep, yep, yep, yep, yep kind of thing. How to do that in a business context.... how to talk on the phone, how to end a conversation, how to deal with separate issues, how to deal with a complaint.'

Presentations (9 responses) were also argued to be a useful tool, both in terms of practicing and learning these skills, gaining confidence and taking students out of their comfort zone. A key activity suggested by participants was to get students up and talking as learning the facets of effective presentation is secondary to actually doing it. Participation also enables development of other attributes such as body language:

'Not just the presentation skills, but personal body language, visual presentations, beginner confidence'

'To actually put a couple of sentences together, might even help their social life. They actually might talk to someone.' 
Activities involving business writing were also commonly recommended, particularly in terms of business letters, business language, attention to detail (spelling) and electronic communication. Interviewees appeared surprised (and dismayed) at the lack of ability in this regard:

'... if you can’t even spell, can’t even spell-check really.....'

'They don’t really know how to even set out a letter.'

Observation was also suggested as an important strategy primarily in terms of observing seasoned practitioners with real clients (4 responses), industry speakers (4) and through mentoring programs. Other strategies include real world case studies (3) and use of commercial software (3).

In addition to the activities suggested, thematic analysis also raised two particular contextual issues. First, it is clear that interviewees were impressed with the technical abilities of students, yet questioned their ability to apply them in a business environment. This led to the call for more activities (role plays, case studies) that focussed on the application and 'doing' type approaches. Second, the issue of professionalism transcended the entire discussion from the need for students to be professionally aware, self-aware and to conduct themselves appropriately in a business environment (including social business environments). This included a need for students to understand and respect that the value of the business is tied to clients and therefore the importance of building relationships with clients and providing them appropriate service:

'It was almost like he was going to school rather than going to work - it was just a lack of professionalism.'

' $\{$ name supressed $\}$ is very, very efficient. But on actual people skills, if she had a call with a client..... she got that done, got off the phone and was onto the next thing. No relationship with the client, there was no bit of banter, bit of a chat.'

'having respect for the value of the firm.'

Overall, the interviewees recommend a range of active learning strategies that focus on generic skills contextualised to the financial planning environment. This could be operationalised through a range of innovative strategies that, to our knowledge, have not been applied in financial planning higher education programs such as service learning programs based on financial literacy community education, simulated WIL through practitioner developed and assessed case based learning, or the development of student advice hypotheticals that include changing client circumstances in the context of game theory and student challenges. The video recording of existing presentation assessment items and client role play exercises, supported by appropriate feedback activities, can also have a positive impact on self-efficacy, oral communication and interpersonal skills (Yakura 2009). Further development of such skills would complement the technical capabilities nurtured in current education programs. We note, however, that developing and implementing such strategies in the current higher education environment will be a challenge as this will require both financial and human capital resources which may not be available or allocated to such pursuits. Furthermore, the ever crowded curriculum, with the common challenge of few financial planning academics on staff may undermine these further. However, with collaboration 
between institutions, the profession bodies and industry, we contend that progress can be made.

\section{LIMITATIONS AND FUTURE RESEARCH}

There are a number of limitations attached to this study including the small sample size, sample location (South East Queensland) and the participants' pre-existing relationship with the Professional Degree. Whilst there was some confusion during interviews when interpreting generic skills the interviewer was able to clarify meanings. Also ethical awareness could also have been added as a tenth generic skill. Future research could compare employer and student perceptions of their skills to identify gaps and address how these gaps in perceptions can be addressed in the financial planning curriculum. Additionally, research could evaluate the generic skills development of students engaging in one or more activities recommended by the participants in this study. A greater sample size would also facilitate future analysis of demographic factors that may have a significant impact on skill importance and skill deficiencies such as the participants' age, length of service in financial planning and educational background, how many graduates the participants have observed and the institutions the graduates completed their studies.

\section{CONCLUSION}

For the proposed educational reforms to financial planning to have traction it is important that they particularly address areas of generic and technical skill importance (the what). To do so requires an understanding of the meanings financial planners ascribe to those skills and why the skills are important or deficient (the why). The educational framework must incorporate learning activities that address the important and deficient skills in a meaningful and effective way (the how). In terms of generic skills, this article provides an instrumental case study involving 24 interviews with financial planning firms which explored the what, how and why of generic skills. These interviews revealed that the three most important skills were oral communication, problem solving (including initiative) and interpersonal skills. Two of these important skills (problem solving and interpersonal skills) were considered to be in the top three greatest skill deficiencies, together with written communication skills. Consequently, it is argued that problem solving and interpersonal skills in particular are areas in need of urgent attention by tertiary institutions currently offering degree and diploma programs in financial planning.

To provide greater contextualisation, the study then explored why the skills are identified as important and deficient related to financial planners and graduates. Finally, insight was provided by industry participants as to how these generic skills could be incorporated and addressed in education programs. This included practice and active learning through participation, role plays and authentic assessment items that got students out of their comfort zones and made them aware of the profession they are about to enter.

It is argued that for these skills to be addressed there needs to be greater coordination and collaboration of stakeholders, particularly universities and industry, as a common theme emerging was "transferability", as students can struggle to apply the skills and knowledge learnt at university in the workplace. This transferability of skills is critical, and may require more partnerships such as work integrated learning, and cross-over programs where industry 
are more active participants in students' tertiary education, a current example of which is the Professional Development Program (Freudenberg et al. 2010 and 2011). This study has expanded the literature by exploring the "why", "how" and "what" of generic skills in financial planning education from a stakeholder perspective. It is envisaged that this exploration can contribute to future discussions involving government, professional associations, employers and higher education institutions in developing an educational framework that meets the needs of an emerging profession.

\section{References}

Atkinson, L, Rizzetti, J \& Smith, S 2005, 'Online resources for work-integrated learning: A case study in re-usability and flexibility', in Balance, Fidelity, Mobility: Maintaining the Momentum? Australasian Society for Computers in Learning in Tertiary Education (ASCILITE), Brisbane, pp37-45.

Australian Association of Graduate Employers (AAGE) 2011, 2011 AAGE Employer Survey, Sydney, accessed 18/08/13, http://www.aage.com.au/index.php/memberservices/surveys-research/employer-survey.

Australian Chamber of Commerce and Industry and Business Council of Australia (ACCI \& BCA) 2002, Employability skills for the future, accessed 20/4/2009, http:/www.dest.gov.au/ NR/rdonlyres/4E332FD9-B268-443D-866C621D02265C3A/2212/final_report.pdf.

Australian Securities and Investments Commission 2003, 'Survey on the quality of financial planning advice', Report No 18, Sydney.

Australian Securities and Investments Commission 2006, 'Shadow shopping on superannuation advice', Sydney.

Australian Securities and Investments Commission 2009, 'Licensing: Training of financial planning advisers', Regulatory Guide 146, Sydney.

Australian Securities and Investments Commission 2011, 'Licensing: Assessment and professional development framework for financial advisers’, Consultation Paper 153, Sydney.

Australian Securities and Investments Commission 2013, 'Licensing: Training of financial product advisers - Updates to RG 146', Consultation Paper 212, Sydney.

Bandura, A 1977, 'Self-efficacy: toward a unifying theory of behavioral change', Psychological Review, vol.84, pp191-215. $\quad$ http://dx.doi.org/10.1037/0033$\underline{\text { 295X.84.2.191 }}$

Bandura, A 1982, 'Self-efficacy mechanism in human agency' American Psychologist, vol.37, no.2, pp122-147. http://dx.doi.org/10.1037/0003-066X.37.2.122

Barrie, S, Hughes, C \& Smith, C 2009, 'The national graduate attributes project: key issues to consider in the renewal of learning and teaching experiences to foster graduate attributes’, Australian Learning and Teaching Council, Sydney.

Bennett, N, Dunne, E \& Carre, C 1999, 'Patterns of core and generic skill provision in higher education’, Higher Education, vol.37, no.1, pp71-93. http://dx.doi.org/10.1023/A:1003451727126

Blackwell, A, Bowes, L, Harvey, L, Hesketh, A \& Knight, P 2001, 'Transforming work experience in higher education', British Educational Research Journal, vol.27, no.3, pp269-285. http://dx.doi.org/10.1080/01411920120048304 
Brimble, M, Cameron, C, Freudenberg, B, Fraser, C \& MacDonald, K 2012, 'Collaborating with industry to enhance financial planning and accounting education', Australasian Accounting Business and Finance Journal, vol.6, no.4, pp79-93.

Bruce, K \& Gupta, R 2011, 'The financial planning education and training agenda in Australia', Financial Services Review, vol.20, no.1, pp61-74.

Cowen, J, Blair, WT, \& Taylor, SM 2006, 'Personal financial planning education in Australian universities', Financial Services Review, vol.15, no.1, pp43-57.

Cull, M 2009, 'The rise of the financial planning industry', Australasian Accounting Business \& Finance Journal, vol.3, no.1, pp26-37.

Dacre Pool, L \& Sewell, P 2007, 'The key to employability: developing a practical model of graduate employability’, Education + Training, vol.49, no.4, pp277-289.

Duijnhouwer, H, Prins, FJ \& Stoking, KM 2012, 'Feedback providing improvement strategies and reflection on feedback use: effects on students' writing motivation, process and performance', Learning and Instruction, vol.22, pp171-184. http://dx.doi.org/10.1016/j.learninstruc.2011.10.003

Financial Planning Association (FPA) 2009, 'Education expectations for professional financial planners', November 2009.

Financial Planning Association (FPA) 2010, 'Education strategy for the financial planning profession', FPA Strategy Paper, accessed 27/9/2011, http://203.210.122.153/fpa/media/FPA/Website\%20files/Pub_11\%20FPA\%20Educatio n\%20Strategy\%20Paper_2010_11_23.pdf.

Financial Planning Education Council (FPEC) 2012, 'Australian Higher Education Curriculum and Accreditation Framework in Financial Planning', Sydney.

Freudenberg, B, Brimble, M \& Cameron, C 2009, 'The building of a professional: creating greater career identity within a degree', The International Journal of Learning, vol.16, no.10, pp253-266.

Freudenberg, B, Brimble, M, \& Cameron, C 2010, 'Where there is a WIL there is a way', Higher Education Research \& Development, vol.29, no.5, pp575-588. http://dx.doi.org/10.1080/07294360.2010.502291

Freudenberg, B, Brimble, M, Vyvyan, V \& Corby, D 2008, 'A penny for your thoughts: can participation in a student-industry conference improve students' presentation selfefficacy and more?', The International Journal of Learning, vol.15, no.5, pp187-200.

Gist, ME \& Mitchell, TR 1992, 'Self-efficacy: A theoretical analysis of its determinants and malleability’, Academy of Management Review, vol.17, no.2, pp183-211.

Goetz, JW, Tombs, JW \& Hampton, VL 2005, 'Easing college students' transition into the financial planning profession’, Financial Services Review, vol.14, pp231-251.

Goetz, JW, Zhu, D, Hampton, VL, Chatterjoe S, \& Salter, J 2011, 'Integration of professional certification examinations with the financial planning curriculum: increasing efficiency, motivation and professional services', American Journal of Business Education, vol.4, no.3, pp35-46.

Hassall, T, Arquero, JL, Joyce, J \& Gonzalez, JM 2013, 'Communication apprehension and communication self-efficacy in accounting students', Asian Review of Accounting, vol.21, no.2, pp160-175. http://dx.doi.org/10.1108/ARA-03-2013-0017

Institute of Chartered Accountants of Australia (ICAA) 2007, 'Key Observations: A Forum on the Financial Planning Industry', Sydney. 
AABFJ | Volume 8, no. 4, 2014 Special Issue on Financial Planning \& Financial Instruments

Institute of Chartered Accountants of Australia (ICAA) and CPA Australia (CPA) 2012, Professional Accreditation Guidelines for Higher Education Programs, accessed 11/9/2013, $\quad$ http://www.cpaaustralia.com.au/cpa-program/information-foracademics/accreditation-guidelines-for-higher-education-programs.

Jackling, B \& De Lange, P 2009, 'Do accounting graduates' skills meet the expectations of employers? A matter of convergence and divergence', Accounting Education, vol.18, no.14/5, pp369-85.

Jackling, B \& Sullivan, C 2007, 'Financial planners in Australia: an evaluation of gaps in technical and behavioral skills', Financial Services Review, vol.16, pp211-228.

Jackson, D 2013, 'The contribution of work-integrated learning to undergraduate employability skills outcomes', Asia-Pacific Journal of Cooperative Education, vol.14, no.2, pp99-115.

Jackson, D \& Chapman, E 2012, 'Non-technical competencies in undergraduate business degree programs: Australian and UK perspectives' Studies in Higher Education, vol.37, no.5, pp541-567. http://dx.doi.org/10.1080/03075079.2010.527935

Jackson, D \& Chapman, E 2013, 'Non-technical skill gaps in Australian business graduates', Education + Training, vol.54, no.2/3, pp96-113.

Kavanagh, M \& Drennan, L 2008, 'What skills and attributes does an accounting graduate need? Evidence from student perceptions and employer expectations', Accounting and Finance, vol.48, no.2, pp279-300. http://dx.doi.org/10.1111/j.1467-629X.2007.00245.x

Krause, MJ 2007, 'Assessing the 'new information professional' beyond college', The CPA Journal, vol.77, no.9, pp68-71.

Lizzio, A \& Wilson, K 2004, 'First-year students' perceptions of capability', Studies in Higher Education, vol.29 no.1, pp109-128. http://dx.doi.org/10.1080/1234567032000164903

Martin, CL 2007, 'Developing a personal financial planning program: more than just courses', Journal of College Teaching \& Learning, vol.4, no.11, pp79-84.

Merino, BD 2006, 'Financial scandals: another clarion call for educational reform - a historical perspective', Issues in Accounting Education, vol.21, no.4, pp363-381. http://dx.doi.org/10.2308/iace.2006.21.4.363

Patrick, C-J, Peach, D, Pocknee, C, Webb, F, Fletcher, M, \& Pretto, G 2009, The WIL [Work Integrated Learning] report: A national scoping study, report sponsored by Australian Learning and Teaching Council (ALTC), Brisbane, QLD.

Precision Consultancy 2007, Graduate employability skills, prepared for Business, Industry and Higher Education Collaboration Council, Barton, ACT.

Purnell, F \& Levy, B 2011. 'The educated adviser', Financial Planning Magazine, accessed 23/9/2011, $\quad$ http://www.financialplanningmagazine.com.au/Article/The-educatedadviser/530604.aspx.

Rossetto, LC \& Murphy, B 2010, 'Embedding communication skills for future financial planners', Australasian Accounting Finance and Banking Journal, vol.4, no.4, pp73-85.

Stake, RE 1995, The art of case study research, SAGE Publications, Thousand Oaks, CA.

Sugara, S, Suzuki, K \& Boland, G 2010, 'Students' major choice in accounting and its effect on their self-efficacy towards generic skills', Asian Review of Accounting, vol.18, no.2, pp131-147. http://dx.doi.org/10.1108/13217341011059390 
Tempone, I, Kavanagh, M, Segal, N, Hancock, P, Howieson, B \& and Kent, J 2012, 'Desirable generic attributes for accounting graduates into the twenty-first century: the views of employers', Accounting Research Journal, vol.25, no.1, pp41-55. http://dx.doi.org/10.1108/10309611211244519

The Association to Advanced Collegiate Schools of Business (AACSB) 2013, AACSB Business Accreditation Standard 9, accessed 11/9/2013, http://www.aacsb.edu/accreditation/business/standards/2013/learning-andteaching/standard9.asp.

Trede, F 2012 'Role of work-integrated learning in developing professionalism and professional identity', Asia-Pacific Journal of Cooperative Education, vol 13, no.3, pp159-167.

Tucker, ML \& McCarthy, AM 2001, Presentation self-efficacy: increasing communication skills through service-learning. Journal of Managerial Issues, vol.13 no.2, pp227-244.

Universities Australia 2008, A national internship scheme: Enhancing the skills and workreadiness of Australian university graduates, accessed 19/8/2013, http://www.universitiesaustralia.edu.au/page/360/submissions---reports/policy-papers/anational-internship-scheme .

Warschauer, $\mathrm{T}$ 2002, 'The role of universities in the development of the personal financial planning profession, Financial Services Review, vol.11, no.3, pp201-216.

Wilton, N 2012, 'The impact of work placements on skills development and career outcomes for business and management graduates', Studies in Higher Education, vol.37, no.5, pp603-620. http://dx.doi.org/10.1080/03075079.2010.532548

Yakura EK 2009, Learning to see: enhancing student learning through videotaped feedback', College Teaching, vol.57, no.3, pp177-183. http://dx.doi.org/10.3200/CTCH.57.3.177$\underline{183}$ 